\title{
Fungi associated with the beetles of Ips typographus on Norway spruce in Southern Poland
}

\author{
ROBERT JANKOWIAK \\ Agricultural Unversity of Cracow, Department of Forest Pathology \\ Al. 29 Listopada 46, PL-31-425 Kraków \\ rljankcrw@cyf-kr.edu.pl
}

J an kowiak R.: Fungi cissociated with the beetles of Ips typographus on Norway spruce in Southem Poland. Acta Mycol. 39 (1): 105-116, 2004.

The mycobiota of the beetles of the phloem-feeding spruce bark beetle, Ips typographus was studied. The most important group of fungi were the ophiostomatoid fungi. Among them $O$. penicillatum was very frequent ophiostomatoid species. Other common fungi were $O$. aimoae, $O$. bicolor, $O$. piceaperdum and $O$. piceae. The ophiostomatoid fungi were often more frequent in beetles collected in galleries than in the bectles caught with a trap. Generally the ophiostomatoid fungi were more often isolated from the beetles bathed in sterile water for 30 seconds. However $C$. polonica, $O$. ainoae, and $O$. minutum occurred most abundantly in the bectles disinfected in $96 \%$ ethyl alcohol for 15 and 30 seconds.

Key words: Ips typographus, Picea abies, ophiostomatoid fungi

\section{INTRODUCTION}

Many phlocophagous bark beetles transport various fungi. The most numerous group are blue-stain fungi belonging to the ascomycete genera Ceratocystis and Ophiostoma and their anamorphs (Wingfield et al. 1993). Most of these fungi causing discolouration of conifers sapwood are saprotrophes or weakly virulent pathogens, but some species are virulent pathogens, which cause serious tree diseases (Br a sier 1991; Harrington 1993).

The Eurasian spruce bark beetle, Ips typographus (Coleoptera: Scolytidae) is one of the important forest pests on various species of spruce. It usually breeds in weakened trees and timber, but when its population increases to high levels, it may also attack healthy trees. I. typographus generally overwinters as adult beetles in the forest litter and flies in the spring. After the flight period the beetles search a suitable host and enter through the bark. The female of $l$ typographus deposes the eggs in brood galleries excavated in the phloem. The larvae feed on the bark and the phloem, making characteristic tunnels (Michalski and Mazur 1999; Skuhravý 2002). While constructing galleries in the bark and the phloem, beetles disseminate fungal 
spores. Propagules of blue-stain fungi may be disseminated by wind or rain but often they are carried by specific insect vectors (Upadhyay 1981). I. typographus has no specialized organs for the transmission of fungal associates. Propagules of these fungi are carried externally in pits on the prononta and elytra and within the digestive system (Furniss et al. 1990; Sol heim 1993). In addition, several mite species associated with I. typographus in Europe (Moser et al. 1989) and with I. typographus f. japonicus in Japan (Moser et al. 1997) play a significant role in transmitting ascospores and conidia of these fungi.

The spruce bark beetle Ips typographus (L.) is an efficient vector of several ophiostomatoid fungi, including Ceratocystis polonica, various Ophiostoma species as well as Leprographium spp. and Pesotum spp. (Siemaszko 1939; KotýnkováSuchrová 1966; Solheim 1986; Harding 1989; Viiri 1997; Kirisits 2001; Kirschner 2001; Viiri and Lieutier 2004; Jankowiak 2004).

The first record of ophiostomatoid fungi associated with 1 . typographus in Poland was made by Siemaszko (1939). He reported that Ceratocystis polonica, Ophiostoma penicillatum, O piceae, $O$. minutum and Graphium pycnocephalum were associated with $I$. typographus in the Białowieza Forest.

The aim of this work was to determine fungi associated with the beetles of $I$. typographus collected in different parts of Southern Poland. Moreover, this study was designed to examine how methods of beetles disinfectation affect on isolation of fungi associated with I. typographus.

\section{MATERIALS AND METHODS}

\section{Study areas, beetle collection and fungal isolation}

The investigations were conducted in the years 1998-2001 on three study plots located in 80 years old montane stands of Picea abies (L.) H. Karst. in the Ustron Forest District (Hołcyna Forest Range, compartment $90 \mathrm{~b} ; 4^{\circ} 43^{\circ} \mathrm{N}, 18^{\circ} 56^{\circ} \mathrm{E} ; 700$ $770 \mathrm{~m}$ above sea level), the Gorce National Park (Lopuszna Forest Range, compartment $756 ; 49^{\circ} 29$ N, $20^{\circ} 08$ E; $790-970 \mathrm{~m}$ a. s. 1.), and the Krynica Experimental Forest (Kopciowa Forest Range compartment $3 \mathrm{~d} ; 49^{\circ} 26 \mathrm{~N}, 20^{\circ} 58^{\circ} \mathrm{E} ; 720-750 \mathrm{~m}$ a.s. 1.). Norway spruce is the dominant tree species in the study areas.

The beetles were collected using two methods. They were caught with a trap or collected from galleries on infested spruce trees. In the first case, the beetles were caught with a trap with commercially prepared IPSLURE ${ }^{\star}$ and IPSODOR ${ }^{\star}$ during their flight period $\left(1^{\mathrm{s}}-30^{\mathrm{th}}\right.$ of May of each year). In the second case, the adult beetles of 1 . typograplus were collected from their galleries in the phloem of Picea abies trees in July. The galleries were taken from weakened, wind-fallen and wind-broken trees as well as from the trap trees. The weakened trees infested by Ips typographus were felled. From parts of the trunk infested by I. typographus 6-8 discs (approximately $20 \mathrm{~cm}$ thick) and chips ( $30 \mathrm{~cm}$ long) with intact bark were cut. In the laboratory the bark was separated from the wood under sterile conditions and the beetles were taken out of the galleries. In total, the beetles were collected from 77 Norway spruce trees.

Before isolation of the fungi, the beetles were bathed in sterile water for 30 seconds, or disinfected in $96 \%$ ethyl alcohol for 15 and 30 seconds. After drying on a 
sterile blotting paper the disinfected beetles were crushed on a microscopic slide and using a sterile scalpel were evenly spread over on the surface of medium. In total, the isolations were performed from 1691 adults of 1 . typographus.

All isolations were made on $2 \%$ malt extract agar ( $2 \%$ MEA; $20 \mathrm{~g}$ malt cxtract, $20 \mathrm{~g}$ agar, $1000 \mathrm{ml}$ distilled water) supplemented with the antibiotic tetracycline (200 $\mathrm{mg}$ per 1 liter of culture medium) to inhibit bacterial growth. Pure cultures of the fungi were also grown on $2 \%$ MEA. The primary isolation plates were incubated at room temperature in the dark. Colonies of fungi growing from the beetles were compared on the basis of macro- and microscopic characteristics, and pure cultures were derived from representative colonies in order to identify the fungi. Typical cultures of each isolated ophiostomatoid taxon have been deposited in the culture collection of the Laboratory of Department of Forest Pathology, Agricultural University of Cracow, Poland.

\section{Data analysis}

The frequency of occurrence of each fungal species was expressed as the percentage of beetles, from which a given species was isolated in relation to the total number of bectles from which isolations were made. Frequencies were computed using the following formula: $F=(N F / N T) \times 100$, were $F$ represents the frequency of occurrence $(\%)$ of each fungal species, NF represents the number of bectles from which a particular fungus was isolated and NT is the total number of beetles from which fungal isolation was attempted.

Only the most frequently isolated fungi were subjected to statistical analysis $(C$. polonica, Ophiostoma ainoae, $O$. bicolor, O. piceaperdum, O. minutum, O. penicillatum and $O$. piceae). For the major fungal associates, contingency tables with Yates'a
correction were used to detect differences between fungal frequencies and applied disinfection methods (Tadeusiewicz et al. 1993; Stanisz 1998). The data were analysed by Statistica ${ }^{*} 6,0$ software.

\section{RESULTS}

\section{Fungal composition}

A total of 42 taxa were identified, and 28 species of fungi were distinguished which did not produce spores or, in spite of fructification, could not be identified. The spectrum of fungi consisted mainly of ascomycetes and anamorphic fungi, but a few zygomycetes and basidiomycetes were also isolated. The most important group of fungi were the ophiostomatoid fungi (14 species). Great part of them ophiostomatoid fungi found belonged to genera Ophiostoma H. et P. Syd. (8 species), Graphium Corda (2 species), Pesotum Crame et Schoknecht (2 species), Ceratocystis Ellis et Halsted (1 species) and Leptographium Lagerberg et Melin (1 species). The most frequent ophiostomatoid species was $O$. penicillatum. Other common fungi were $O$. ainoae, $O$. bicolor; $O$. piceaperdum and $O$. piceae. C. polonica, G. fimbriisporum, $O$. flexuosum and $O$. minutum were generally rare. Species not belonging to the ophiostomatoid fungi were relatively rare. In this group, one ascomycete Petriella sordia as well as anamorphic fungi and zygomycetes (Trichoderma sp., Candida sp., Phoma 
sp., Cytospora sp. and Mucor sp.) were most abundant. Among basidiomycetes Gloeocystidium ipidophilum was most commonly isolated (Tab. 1).

The ophiostomatoid fungi were often more frequently found on the beetles collected from galleries than on the beetles caught in the traps. Among these, $O$. piceaperdum occurred only more frequently in the beetles caught with a trap. In contrast to the ophiostomatoid fungi, other species were frequently isolated from the beetles caught in the traps (Tab. 1).

\section{Table 1}

Fungi isolated from the beetles of Ips tpograpluts collected from galleries (BG) and from traps (BT)

\begin{tabular}{|c|c|c|}
\hline \multirow{2}{*}{ Fungi } & \multicolumn{2}{|c|}{ Frequencies of occurrence (\%) } \\
\hline & BG & BT \\
\hline \multicolumn{3}{|l|}{ Ophiostomatoid fungi } \\
\hline \begin{tabular}{|l|} 
Ceratocystis polonica (Siem.) C. Morcau \\
\end{tabular} & 13.2 & 2,0 \\
\hline Ophiostomm ainone Sollheim & 35.2 & 23.3 \\
\hline Ophiostona bicolor Davids. et Wells & 32.8 & 16.2 \\
\hline Ophiostona cucullaum Solheim & 3.5 & 0.3 \\
\hline Ophiostoma flexiosum Solheim & 7.3 & 2.2 \\
\hline Ophiostona minutum Siem. & 4.7 & 2.3 \\
\hline Ophiostona penicillatum (Grosm.) Siem. & 58.5 & 34.3 \\
\hline Ophiostoma piceae sensu lato & 23.3 & 12 \\
\hline Ophiostoma piceopesdum (Rumb.) von Arx & 12.5 & 17 \\
\hline Graphutum fimbrispontm (Morelet) Jacobs, Kirisits et Wingf. & 6.7 & 4.7 \\
\hline Graphitum pveroocephatum Grosm. & 0.1 & \\
\hline Leprographitun eupinyes Jacobs et Wingf. & 0.1 & 0.9 \\
\hline Pesoftun sp. 1 & 39 & 1.8 \\
\hline Pesolum sp. 2 & 0.2 & 0.4 \\
\hline \multicolumn{3}{|l|}{ Other } \\
\hline Acremonium sp. & 0.8 & 2.2 \\
\hline Altemana alternata (Fr.) Keissl. & 0.1 & \\
\hline Candida sp. & 7 & 16.7 \\
\hline Cerocorticiun cf. notabile (Jacks.) Jülich et Stalp. & 1.4 & 0.5 \\
\hline Cladosporium cladosporioides (Fresen.) de Vries & & 0.2 \\
\hline Cylindrocamon sp. & & 3.4 \\
\hline Cytospora sp. & & 1.3 \\
\hline Disconycetes sp.1 & & 0.4 \\
\hline Drechsiem pone (Baudys) Schoemaker & & 0.5 \\
\hline Epicoccum nigram Link & & 0.6 \\
\hline Fusaritum sp. & & 0.2 \\
\hline Gleocladium sp. & & 0.8 \\
\hline Glococysididum ipidophilum Siem. & 2.3 & \\
\hline Hormonema sp. & & 22 \\
\hline Monodictys castarieae (Wallr.) Hughes & 0.1 & \\
\hline Montierelia isabeilina Oudem. & 0.1 & 1 \\
\hline Mucor mucedo Mich et St.-Am. & & 0.4 \\
\hline
\end{tabular}


Tab, 1 cont.

\begin{tabular}{|c|c|c|}
\hline Mucor sp. & 79 & 17.4 \\
\hline Petriclla sordida (Zukal) Barron et Gilman & 2.2 & 0.9 \\
\hline Pezizellet sp. & & 0.1 \\
\hline Phoma sp. & & 3.7 \\
\hline Roffacica sp. & & 0.1 \\
\hline Rhinocladiella atrovirens Nannf. & & 0.3 \\
\hline \begin{tabular}{|l} 
Sclenotium sp. \\
\end{tabular} & 0.1 & 0.3 \\
\hline Sondaria fimicola (Roh.) Ces et de Not. & & 0.1 \\
\hline \begin{tabular}{|l} 
Stachybotiys atna Corda \\
\end{tabular} & & 1.5 \\
\hline Trichoderma sp. & 5.2 & 10 \\
\hline Uloctadiun sp. & & 0.9 \\
\hline \multicolumn{3}{|l|}{ Unidentified: } \\
\hline Basidiomycosa (6 species) & & 0.8 \\
\hline Others (22 species) & 0.8 & 1.8 \\
\hline Number of investigated beetles & 789 & 902 \\
\hline Number of "sterile" beetles & 9 & 66 \\
\hline
\end{tabular}

The composition of the mycobiota was quantitatively different at various study plots. The pathogenic species Ceratocystis polonica occurred most frequently on the 1. typographus beetles from Lopuszna, where it was isolated in $2.7 \%$ to $24.5 \%$ of the cases. In contrast, it was sporadically isolated from the beetles collected in Holcyna.

\section{Table 2}

Frequency $(\%)$ of ophiostomatoid fungi isolated from the beetles of $I$. typograpius on three study plots ( $\mathrm{L}$ - Lopuszina, $\mathbf{H}$ - Hołeyna, $\mathbf{K}$ - Kopciowa)

\begin{tabular}{|c|c|c|c|c|c|c|}
\hline \multirow{3}{*}{ Fungi } & \multicolumn{6}{|c|}{ Isolated from } \\
\hline & \multicolumn{3}{|c|}{$\mathrm{BG}$} & \multicolumn{3}{|c|}{ BT $^{*}$} \\
\hline & $\mathrm{L}$ & $\mathrm{H}$ & $\mathrm{K}$ & $\mathbf{L}$ & $\mathbf{H}$ & $\mathrm{K}$ \\
\hline Ceratocystis polonica & 24.5 & 3 & 8.2 & 2.7 & 23 & 1 \\
\hline Ophiosiona ainoae & 26.6 & 30.3 & 56.4 & 15.6 & 20.9 & 33 \\
\hline Opiniostoma bicolor & 20.2 & 54.3 & 24.6 & 14.9 & 21.9 & 11.8 \\
\hline Opinostoma cucullatum & 1.2 & 7.1 & 2.6 & 0 & 0.3 & 0.6 \\
\hline Opinostoma flexuosum & 2.7 & 0.7 & 24.1 & 1 & 1 & 4.6 \\
\hline Ophiostoma minutum & 2.1 & 3.7 & 10.3 & 1.7 & 1.3 & 3.9 \\
\hline Oplúostoma pericillatum & 60.9 & 53.9 & 61 & 34.9 & 32.6 & 35.3 \\
\hline Ophtostoma piceae sensu lato & 12.5 & 30 & 32.3 & 13.2 & 8.3 & 14.4 \\
\hline Ophiosloma piceaperdum & 8.9 & 10.9 & 21 & 10.8 & 13 & 26.8 \\
\hline Graphium fimbrïspormm & 0.6 & 6 & 17.9 & 3 & 2.6 & 8.2 \\
\hline Graphium pycnocephalum & 0 & 0 & 0.4 & 0 & 0 & 0 \\
\hline Lepiogrophitum etupliyes & 0 & 0 & 0.4 & 0 & 2 & 0.6 \\
\hline Pesottum sp. 1 & 4.6 & 3.7 & 3.1 & 1.4 & 0 & 3.9 \\
\hline Pesotium sp. 2 & 0.3 & 0 & 0.4 & 1.4 & 0 & 0 \\
\hline $\begin{array}{l}\text { Number of investigated the } \\
\text { beetles }\end{array}$ & 327 & 267 & 195 & 295 & 301 & 306 \\
\hline
\end{tabular}


O. penicillatum was most common in all plots except one (in Holcyna), where $O$. bicolor was the most abundant species on the beetles collected from the galleries. Among the study plots, $O$. ainoae, $O$. flexuosum, $O$ mintum, $O$. piceae $O$. piceaperdum and $G$. fimbriisporum occurred most frequently in the beetles of $I$. typographus in Kopciowa (Tab. 2).

\section{Comparison of frequencies of ophiostomatoid fungi with different disinfectation methods of the beetles of I. typographus}

The methods of beetles disinfectation had relatively strong influence on the result of fungi isolation. More significant differences were found when fungi were isolated from the beetles collected from the galleries of $L$. typographus than the beetles caught with a trap. Gencrally the ophiostomatoid fungi were more often isolated from the beetles bathed in sterile water for 30 seconds. However $C$. polonica, $O$. ainoae, and $O$. minutum occurred most abundantly in the beetles disinfected in $96 \%$ ethyl alcohol for 15 and 30 seconds (Tab. 3).

In the case of the beetles collected from galleries of I. typographus, O. penicillatum $(67.7 \%)$, O. piceae $(40.3 \%), O$. bicolor $(40,3 \%)$ and $O$. ainoae $(33.8 \%)$ were most frequently isolated from the beetles, which were bathed in sterile water for 30 seconds. The beetles disinfected in $96 \%$ ethyl alcohol for 15 seconds were most frequently colonized by $O$. penicillatum $(57.5 \%)$, O. ainoae $(39.3 \%), O$. bicolor $(31.9 \%)$ and O. piceae $(17.5 \%)$. O. penicillatum $(54.0 \%)$, O. ainoae $(32.3 \%)$, O. bicolor $(26.2 \%)$ and $C$. poionica (20.4\%) occurred most frequently in the beetles disinfected in $96 \%$ ethyl alcohol for 30 seconds (Tab. 3). Among the ophiostomatoid fungi tested, the frequencies of $O$. ainoae i $O$. piceaperdum were least affected by the different methods of beetles disinfectation (the differences were not significant). For other ophiostomatoid fungi the most significant differences were between the beetles bathed in

\section{Table 3}

The most abundant species in the assemblages of ophiostomatoid fungi isolated from the beetles depending on methods of beetles disinfection, and statistical evaluation of differences in their frequency (based on chi-square test)

\begin{tabular}{|c|c|c|c|c|c|c|}
\hline \multirow{3}{*}{ Fungi } & \multicolumn{6}{|c|}{ Perecntage in quantitative structure of a assemblage } \\
\hline & \multicolumn{3}{|c|}{ beetles from galleries } & \multicolumn{3}{|c|}{ beetles from traps } \\
\hline & 1 & II & III & I & II & III \\
\hline Cernocystis polonica & $3.42^{\mathrm{ac}}$ & $15.59^{\prime}$ & $20,45^{*}$ & $0.63^{\prime}$ & $4.33^{\text {ab }}$ & 1.29 \\
\hline Ophiostona ainoae & 33.84 & 39.34 & 32.32 & 20.57 & 22.74 & 26.54 \\
\hline Optuostoma bicolor & $40.30^{\mathrm{m}}$ & 31.94 & 26.24 & $10.44^{\alpha}$ & $16.61^{*}$ & $21.68^{\circ}$ \\
\hline Ophiostona mintumi & 4.94 & $6.4 G^{\circ}$ & $2.66^{\circ}$ & 1.58 & 1.81 & 3.56 \\
\hline Ophiostoma penicullatum & $67.68^{k}$ & $57.49^{-1}$ & $53.99:$ & 35.44 & 30.69 & 36.25 \\
\hline Opthiostouna piceat & $40.30^{n}$ & $17.49^{\prime}$ & 12.17 & 12.66 & 10.47 & 12.62 \\
\hline Opliostoma piceaperdum & 15.58 & 11.03 & 10.98 & $23.42^{*}$ & $10.83^{*}$ & $15.86^{\circ}$ \\
\hline
\end{tabular}

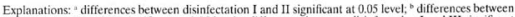
disinfectation II and III significant at 0.05 level; " differences between disinfectation I and III significant at 0.05 level; 1 - beetles bathed in sterile water for 30 sec: II - beetles disinfected in $96 \%$ ethyl alcohol for $15 \mathrm{sec}$; $11 \mathrm{l}$ - beetles disinfected in $96 \%$ ethyl alcohol for 30 sec. 
sterile water for 30 seconds, and the beetles disinfected in $96 \%$ ethyl alcohol for 15 and 30 seconds (Tab, 3 ).

In the case of the bectles of $I$. typographus caught with a trap, $O$. penicillatum $(35.4 \%), O$. piceaperium $(23.4 \%), O$. ainoae $(20.6 \%)$ and $O$. piceae $(12.7 \%)$ were most frequently isolated from the beetles bathed in sterile water for 30 seconds. The beetles disinfected in $96 \%$ ethyl alcohol for 15 seconds were most frequently colonized by $O$. penicillatum $(30.7 \%), O$. ainoae $(22.7 \%), O$. bicolor $(16.6 \%)$ and $O$. piceaperdum $(10.8 \%)$. From the beetles disinfected in $96 \%$ ethyl alcohol for 30 seconds $O$. penicillatum $(36.2 \%)$, O. ainoae $(26.5 \%)$. O bicolor $(21.7 \%)$ and $O$. piceaperdum $(15.9 \%)$ were most frequently isolated. The frequencies of majority of the ophiostomatoid fungi $(O$. ainoae, $O$. minutum, $O$. penicillatum and $O$. piceae) were least affected by the different methods of disinfectation of the beetles (the differences were not significant).

\section{DISCUSSION}

The assemblage of ophiostomatoid fungi as the one recorded in the present study is associated with I. typographus also at other parts of its distribution range in Europe (Siemaszko 1939; Mathiesen-Käärik 1953; Kotýnková-Suchrová 1966; Solheim 1986; Harding 1989; Jankowiak 2001; Viiri 1997; Grubel. nik 1998; Kirschner 1998; Kirisits 2001, 2004) and in Japan (Yamaoka et al. 1997). Recently Viiri and Lieutier (2004) have studied the mycobiota of $I$. typographus in three areas in France and have recorded the same fungi as those occurring in other parts of Europe. In a comprehensive study Yamaoka et al. (1997) reported 9 ophiostomatoid fungi associated with I. typographus f. japonicus in Japan and only $O$. japonicum was not found during the present study. All of the fungi reported by Grubelnik (1998) and Kirisits (2001) in Austria were also isolated from I. typographus beetles in this study. In the Norwegian study, Solhe im (1986) isolated 10 specics of ophiostomatoid fungi from discoloured wood of Picea abies, and only $O$. terropii Mathiesen was not found during the present study. This Ophiostoma species is mainly associated with cerambycid beetles from genus Tetropium Kirby (Mathiesen 1951: Upadhyay 1981; Jacobs et al. 2003a), which commonly infest spruce trees already colonised by $I$. typographus and often initiate their galleries in the vicinity of breeding systems of the spruce bark beetle. In Denmark and Sweden. Harding (1989) reported 16 species of ophiostomatoid fungi, of which $O$. cainii (Olchow. et Reid) Harrington and $L$. Lundbergii Lagerb. et Melin were not found during the present study. In Germany, Kirschner (2001) found 12 species of ophiostomatoid fungi. In this group Ceratocystiopsis alba (de Vay, Davidson et Moller) Upadhyay, O. arraucariae (Butin) de Hoog et Scheffer, O. japonicum Yamaoka et Wingf. and $O$. obscura (Davidson) von Arx were not found during the present study. Such a high diversity of ophiostomatoid fungi associated with $I$. typographus between the studies conducted in Germany and in Poland is probably due to the completely different investigatory methods used in both studies. Also in Germany Kirschner and Oberwinkler (1999) found O. neglectum Kirschner et Oberwinkler to be associated with $I$. typographus. This species probably remained undetected in the present study because it is mainly transmitted by Dryocoetes 
autographus (Ratz.) and Hylurgops palliatius (Gyll.), which colonise weakened trees or logs and often infest trees in the same time or after I. typographus.

Sicmaszko (1939) recorded only 5 ophiostomatoid fungi in the previous investigations in North-Eastern Poland. All of the fungi displayed by Siemaszko were also found in this study. In the study on the entomopatogenic fungi Ba a zy (1969) reported 2 ophiostomatoid fungi, including Graphium penicillioides Corda.

Among the ophiostomatoid fungi, Leptographium etuphyes, Graphium fimbriisporum and $G$. pycnocephalum have rarely been mentioned as associates of $I$. typographus. Leptographitum euphyes was only reported in association with I. ty. pographus by J ankowiak (in press). Graphitum fimbriisporum was mainly mentioned by Kirisits (1996, 2004), Grubelnik (1998), Jacobs et al. (2003b) in Austria where it was an important associate of $I$. typographus and by Jankowiak in Poland. G. pycnocephalum was reported as frequent associate of I. typographus in Poland (Siemaszko 1939) and rarely in Germany, Sweden (Kirisits 2004) and former Czechoslovakia (Kotýnková-Suchrová 1966). Among Ophiostoma species, $O$. flexuosum has seldom been mentioned as associates of $I$. typographus. It was only found to be associated with $I$. typographus in Germany, Denmark and Sweden (Harding 1989), Norway (Solheim 1986) and Poland (Jankowiak 2001).

Besides $O$. piceapardum all of the ophiostomatoid fungi occurred most abundantly on the beetles collected from the galleries than on the beetles caught with a trap. Since the beetles of $I$. typographus hibernate in the soil, they are easily contaminated with spores of litter and soil fungi like Mucor sp. and Penicillium sp. These fungi could have had antagonistic influence on the growth of the ophiostomatoid fungi, since they produce volatile and non-volatile organic compounds limiting the growth of the pathogens (Wells and Bell 1979; Kwasna 1987). Probably the bectles in the trap are stronger contaminated with spores of antagonistic fungi.

Frequency of the fungal associates of the beetles I. typographus was considerably different from the results of the previous studies (Siemaszko 1939; Solheim 1986; Harding 1989: Viiri 1997; Kirschner 2001; Kirisits 2004). A similar spectrum of ophiostomatoid fungi as that recorded on the beetles in this study was found also on larvae and in galleries of I. typographus by Jankowiak (2001, 2004, in press). In the present study $O$. penicillaum was the most commonly found species, whereas the pathogenic species C. polonica was found only infrequently, especially on the beetles caught with a trap. A similar results as that recorded from this study were obtained by Y amoaka et al. (1997) who isolated $O$. ainoae, $O$, piceae, $O$. bicolor and $O$. penicillatum from the beetles of Ips typographus f. japonicus with a frequency of occurrence greater than $30 \%$. In contrast to this study, Sicm aszko (1939) found C. polonica, O. penicillatum and Graphium pycnocephalum to be the most common, and $O$. piceae and $O$. minuta less common associates of $I$. typographus. There were big quantitative differences in the composition of the mycobiota of the beetles 1 . lypographus at various localities in this study. The quantitative differences have mainly been documented for the most virulent $C$. polonica, but also for other fungal associates of the spruce bark beetle. C. polonica occurred at high frequencies in North-Eastern Poland (Sie maszko 1939), in Norway (Solheim 1993) and at some localities in Austria (Kirisits 
2001). In contrast, it was not recorded at all in former Czechoslovakia (Kotýnková-Suchrová 1966) and only rarely in Sweden and Denmark (Harding 1989), Finland (Viiri 1997), Gcrmany (Harding 1989, Kirschncr 1998, 2001) and France (Salle et al. 2003). It was also relatively frequently recorded in a recent study conducted in France (Viiri and Lie utier 2004). These results show a big variation in the abundance of blue-stain fungi associated with I. typographts at different parts of the distribution range of this insect in Europe. The variation of the mycobiota of $I$. typographus between different localities in Europe was explained by different researchers (Harding 1989; Solheim 1993; Kirisits 2004). Ki$r$ isits (2004) accepts that the methodology employed in different studies may often be very important (especially the differences in timing and methods of fungal isolation). Qualitative and quantitative differences in the composition of the mycobiota of $I$. typographus may also be dependent on the population dynamics of $I$. typographus (Solheim 1992a, 1993). Kirisits (2004) suggested that the climate has a strong influence on the frequency of ophiostomatoid fungi. Following this hypothesis, $C$. polonica, which has a relatively low temperature tolerance (maximum around $31-32^{\circ} \mathrm{C}$ ) may be replaced by other fungi such as $O$. bicolor with a higher temperature tolerance (Solhe im 1991).

Basidiomycetes have only occasionally been reported as associates of bark beetles (Siemaszko 1939; Whitney et al. 1986; Kirschner 2001; Kirisits 2004). Among the basidiomycetes, $G$. ipidophilum and Cerocoricium cf. notabile have been identified. These species were relatively rare associates of the beetles 1 . typographus in Southern Poland, but from the present study it is concluded that $I$. typographus acts as a vector of $G$. ipidophilum and $C$. notabile. $G$. ipidiophilum has been reported in Poland (Siemaszko 1939), Germany (Kirschner 1998) and Austria (Grubelnik 1998). The common basidiomycete reported by Solheim (1992b) in Norway represents also $G$. ipidiophilum. The non-ophiostomatoid fungi were frequently carried by the beetles $I$. typographus in this study. These fungi represent wood-colonising fungi (Rhinocladiella atrovirens), mycoparasitic and mycophilic fungi (Gliocladium sp., Trichoderma sp.), phytopathogenic fungi (Alternaria alternata, Pestalotia hartigii, Cylindrocarpon sp., Fusarium sp.) and other ecological groups.

The results of this study confirmed that the beetles of $I$. typographus transport spores of fungi laterally on the pronota and elytra as well as in the digestive tract. Generally $C$. polonica, $O$. ainoae, and $O$. minutum occurred most abundantly on the beetles disinfected in $96 \%$ ethyl alcohol for 15 and 30 seconds than on the bectles bathed in sterile water for 30 seconds. This difference may be caused by the variation between beetles, presence of the antagonistic fungi on the surface of the pronota and elytra or some other factors.

This study showed, that ophiostomatoid fungi are the most frequent species transmitted by I. typographus. These species were found more frequently when fungi were isolated from the bectles collected from the galleries of $I$. typographus than the beetles caught with a trap. The varying frequencies of ophiostomatoid fungi should be linked with strong contamination of the beetles from the traps by conidia of saprotrophic fungi. 


\section{REFERENCES}

Balazy S. 1966. Organizmy zywe jako regulatory liczebnošci populacji korników w drzewostanach swierkowych ze szczególnym uwzglę̧nieniem owadobójczych grzybów. PTPN. Prace Kom. Nauk Roln. i Kom. Nauk Lḉn. 21: 1-50.

Brasie r C. M. 1991. Ophiostoma thova-ulmi sp. nov., causative agent of current Dutch elm discase pandemics. Mycopathologia 115:151-161.

Furniss M. M., Solheim H., Christiansen E. 1990: Transmission of blue-stain fungi by lps $t$ pographits (Coleopterd: Scohtridae) in Norway spruce. Ann. Entomol. Soc. Am. 83: 712-716.

Grubelnik R. 1998 . Untersuchungen uber die Zusammensetzung der Mycoflora von Jps typographus auf ausgewahlten Wald-Standorten in Osterreich unter besonderer Berücksichtigung der pathoge. nen Art Ceratocysis polonica. Diplomarbeit, Universitit fur Bodenkultur Wien.

Harding S 1989. The influence of mutualistic blue stain fungi on bark beetle population dynamics. Ph.D. thesis. Department of Zoology, Royal Veterinary et Agricultural University. Copenhagen.

Har ringt on T. C. 1993. Discascs of conifers caused by species of Ophiostona and Leprographium. (In:) M. J. Wingfield, K. A. Seifert. J. F. Webber (cds). Cenatocystis and Ophiostoma. Taxonomy, ecology and pathogenicity: 161-172. St Paul, MN, Amer. Phytopathol. Soc.

Ja cobs K., Seifert K.A., Har rison K.J., Kirisits I 2003a. Identity and phylogenetic relationships of ophiostonatoid fungi associated with invasive and native Tetropiun species (Coleoptera: Ceram. bycidae) in Allantic Canada. Can. J. Bot. 81: 316-329.

J a cobs K. Kirisits T, Wing field M. J. 2003b. Taxonomic re-evaluation of three related species of Gropirium. based on morphology, ecology and phylogeny. Mycologia 95: 714-727.

Ja nkowiak R. 2001. Grzyby z rzẹdu Ophiostomatales wyizolowane z larw komika drukarza (Ips typograpius L.). Materialy z V Konferencji Sekcji Chorób Roślin Drzewiastych Polskiego Towarzystwa Fitopatologiczncgo: 47-55. Poznań - Blażcjewko 29 maj-1 czcrwicc.

Jankowiak R. 2004. Ophiostomatoid fungi associated with the spruce bark beetle - Ips typographus (L.) new for Poland: occurrence and morphology. Phytopathol. Pol., in press.

Jank owiak R. Fungi associated with Ips typograplus on Picea abies in Southern Poland and their succession into phloen and sapwood of beetle-infested trees and logs. Forest Pathology, in press.

Kirisits T 1996 Untersuchungen uber die Vergesellschaftung von Bläepilzen (Ceratocystis/Ophios* toma spp.) mit den rindenbrutenden Fichtenborkenkifem Ips typographas, Pinogenes chalcographus und Hylurgops glabratıs in Österreich. Diplomarbeit. Universität für Bodenkultur Wien.

Kirisits T: 2001. Studies on the association of ophiostomatoid fungi with bark beetles in Austria with special cmphasis on lps trpographus and Ips cembrac and their associated fungi Ceratocystis polonica and Ceroloctstis laricicola. Dissertation. Universitat fur Bodenkultur Wien.

Kirisits T. 2004. Fungal associates of European bark beetles with special emphasis on the ophiostomatoid fungi. (In:) F. Lieutier, K. R. Day, A. Battisti, J. C. Grégoire, H. Evans (eds), Bark and Wood Boring Insects in Living Trees in Europe, A Synthesis. Dordrecht; Kluwer. In press.

Kirschner R. 1998. Diversität mit Borkenkäfern assoziierter filamentöser Mikropilze. Dissertation. Eberhard-Karls-Universitat Tubingen.

Kirschner R. 2001. Diversity of filamentous fungi in bark beetle galleries in central Europc. (In:) J. K. Misr a (ed.). Thichomcetes and other fungal groups: 175-196. Robert W. Lichtwardt Commemoration Volume. Enfield, Plymouth: Science Publishers, Inc.

Kirschner R., Oberwin kle r F. 1999. A new Ophiostoma species associated with bark beetles infesting Norway spruce. Can. J. Bot. 77: 247-252.

Kotýnková.Suchrová E. 1966. Mykoflóra chodeb kúroveũ v Ceskoslovensku. Ćeská Myeol. 20: 45. 53.

Kw aśna H. 1987. Mozimośc uzycia saprofitycznych grzybów glebowych do ochrony siewek sosny zwyezajnej przed zgorzela powodowaną przez Fusarium oxysponim Schl. i Rhizoctonia soleni Kühn. Rocz Nauk Roln. Ser. E $18(2): 115-11$.

Mathiesen-Käarik. A. 1953. Eine Übersicht über die gewöhnlichsten mit Borkenkäfern assoziierten Bliuepilze in Schweden und cinige für Schweden neue Blãuepilze. Meddelanden Statens Skogforskningsinstitutut $43: 1-74$.

Michalski J. Ma zur A. 1999. Korniki. Praktyczny przewodnik dla lé́ników. Oficyna Edytorska „Wy. diwnictwo Swiat", Warszawa. 
Mose r J., Perry T., Solhe im H. 1989. Ascospores hyperphoretic on mites associated with Ips typograpirus. Mycol. Res, 93:513-517.

Mosef J., Perry T, Furuta, J. 1997. Phoretic mites and their hyperphoretic fungi associated with fly. ing Ips npograpulus japanicus Niijima (Cof.. Scohvidae) in Japan. J. Appl. Ent. 121: 425.428.

Salle A., Yart A., Garcia J., Romary P. Lie utie r F. 2003. Fungi associated with Ips typographus (L.) in France: Virulence and diversity in relation to bark beetle population levels. (In:) Book of Abstracts of a mecting of IUFRO working party S 7.03,05 (Integrated Control of Scolytid Bark Beetles). Blodgett Forest Research Station. Georgetown, California, September 29 - October 2, 2003.

Siemaszko W. 1939. Zespoly grzybów towarzyszacych kornikom polskim. Planta Pol. 7: 1-54.

Solhe im H. 1986. Species of Ophiostomataceat isolated from Picea abies infested by the bark beetle Ips npographus. Nord. J. Bot. 6: 199-207.

Solheim H. 1991 . Oxygen deficiency and spruce resin inhibition of growth of fungi associated with Jps npographits. Mycol. Res. 95: 1.387-1392.

Solhei $\mathrm{m}$. 1992a. The early stages of fungal invasion in Norway spruce infested by the bark beetle Ips topographus. Can, J. Bot. 70: 1-5.

Solhei $\mathrm{m}$ H. 1992b. Fungal succession in sapwexod of Norway spruce infested by bark beetle ips typograpins. Eur. J. For. Path. 22: 136-148.

Solhei $\mathrm{m} \mathrm{H}$.1993. Ecological aspects of fungi associated with the spruce bark beetle Ips typogrophus in Nonway. (In:) M. J. Wingfield, K. A. Seifert, J. F. Webber (eds). Ceratocystis and Ophiostoma Taxonomy, ecology and pathogenicity: 235-242. St Paul, MN, American Phytopathological Society. Skuhravỳ V. 2002. Lỷkożrout smrkovy Ips fypographus (L.) a jeho kalamity. Agrospoj, Praha.

Stanisz A. 1998 Przystẹpny kurs statystyki. StatSoft Polska Sp. zo. o, Kraków.

Tadeusiewicz R., Izwofski A., Majewski J. 1993. Biometria. Wyd. AGH. Kraków.

Upad hy ay H. 1981. A monograph of Ceratocystis and Ceratocystiopsis. The University of Georgia Press, Athicns.

Viiri H. 1997. Fungal associates of the spruce lark beetle Ips typographus L. (Col. Scolytidae) in relation to difterent trapping methods. J. Appl. Entomol. 121: 529-533.

Viiri H. Lieutier F. 2004. Ophiostomatoid fungi associated with the spruce bark bectle, Ips ty. pographus, in three areas in France. Ann. For. Sci. 61: 215-219.

Yamaoka Y.. Wingfield M. J.. Takahashi 1., Solheim H. 1997. Ophiostomatoid fungi associated with the spruce bark beetle Ips typogrupinus f. japonicus in Japan. Mycol. Res. 101: 1215-1227.

Wells H. D., Bell D. K. 1979. Variable antagonistic reaction in vitro of Trichoderma herziamum against several pathogens, Phytopathol. 69(9): 1048-1049.

Whitney H S. Bandoni R. J., Oberwinkler. 1986. Entomoconicium dendrocioni gen. et sp. nov. (Basidionveotina). a possible nutritional sy mbiote of the mountain pine bectle in lodgepole pine in British Columbia. Can. J. Bot. 65:95-102.

Wingfield M. J. Seifert K. A. Webber J. F. (eds) 1993. Ceratocystis and Ophitosioma. Taxonomy. ecology and pathogenicity, St Paul, MN: Amer. Phylopathol. Soc.

\section{Grzyby towarzyszące chrząszczom Ips typographus na świerku pospolitym w poludniowej Polsce}

\section{Streszczenie}

Badano grzyby towarzyszące chrząszczom Ips typographus w trzech rejonach pohudniowej Polski oraz okreslono wplyw różych metod dezynfekcji chrzaszczy na wynik izolacji grzybów. Wśród izolatów grzybów wyrózniono ponad 70 gatunków, głównic grzybów workowych i mitosporowych. Do najcześciej zwiazanych z kornikiem drukarzem należaly grzyby ofiostomatoidalne: Ophiostoma penicillatum, $O$. amoae, $O$. bicolor; $O$. piceaperdum i $O$. piceae. Gatunki nie nalcżące do grzybow ofiostomatoidalnych byly stosunkowo rzadkie. W tej grupie najliczniej reprezentowane byly: Candida sp., Cytospora sp., Mucor sp., Petriella sordia, Phoma sp. i Trichoderma sp. 
Prawie wszystkie gatunki grzybów ofiostomatoidalnych byly częściej izolowane z chrząszczy zebranych z zerowisk kornika drukarza, a inne gatunki grzybów zwiększaly częstość występowania w przypadku chrzązzczy odławianych do pulapek feromonowych.

Na wynik izolacji grzybów stosunkowy duży wpływ miały metody dezynfekcji chrząszczy, zwlaszcza dla chrząszczy zebranych z żerowisk kornika drukarza. W większości przypadków grzyby ofiostomatoidalne byly częścicj izolowane z chrząszczy moczonych przez 30 sekund w wodzie sterylnej. Jednak takie gatunki jak Ceratocystis polonica, $O$. ainoae, i $O$. mintum stwierdzano częściej na chrząszczach dezynfukowanych przez 15 lub 30 sekund w $96 \%$ alkoholu etylowym. 